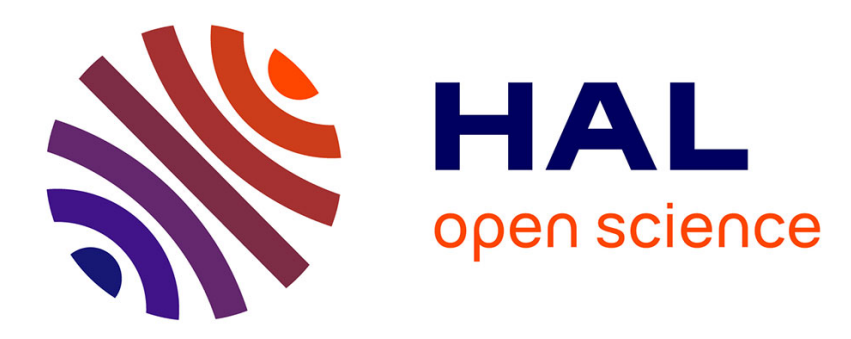

\title{
The Geography of Civil Unions in Vermont
}

Baptiste Coulmont

\section{To cite this version:}

Baptiste Coulmont. The Geography of Civil Unions in Vermont. Journal of Lesbian Studies, 2005, 9

(1-2), pp.185-195. 10.1300/J155v09n01_17 . halshs-00768666

\section{HAL Id: halshs-00768666 \\ https://shs.hal.science/halshs-00768666}

Submitted on 22 Dec 2012

HAL is a multi-disciplinary open access archive for the deposit and dissemination of scientific research documents, whether they are published or not. The documents may come from teaching and research institutions in France or abroad, or from public or private research centers.
L'archive ouverte pluridisciplinaire HAL, est destinée au dépôt et à la diffusion de documents scientifiques de niveau recherche, publiés ou non, émanant des établissements d'enseignement et de recherche français ou étrangers, des laboratoires publics ou privés. 


\title{
The Geography of Civil Unions in Vermont
}

\author{
Baptiste Coulmont
}

\author{
Translated by Mary Eichbauer
}

Preliminary version of an article published as :

Coulmont, Baptiste. "The Geography of Civil Unions in Vermont", Journal of Lesbian

Studies, 2005, vol.9, n¹/2, pp.185-195, doi:10.1300/J155v09n01_17

This article is a translation (by Mary Eichbauer), the original French version was published as :

Coulmont, Baptiste. "Géographie de l'union civile au Vermont", Mappemonde, 2003-3, $\mathrm{n}^{\circ} 71, \mathrm{pp} .13-18$

\begin{abstract}
In 2000, Vermont established "civil unions" meant for same-sex couples. This form of marriage relied on the existence of a local gay and lesbian community, while contributing to the development of "gay and lesbian tourism" and pushing certain churches to revisit their treatment of same-sex couples. Gay and lesbian rights and rural communities are not mutually exclusive.
\end{abstract}

Key words:

civil unions, same-sex couples, lesbian and gay couples, gay and lesbian tourism, lesbians and gay men in rural communities? 
Vermont, which declared its independence from England in 1777, was the first state after the thirteen original colonies to be admitted to the Union in 1791. "Thereafter, rural Vermont played a decreasing role in the growing nation," writes one encyclopedia. Vermont is one of the smallest of the American states $(0.2 \%$ of its total area) and one of the least populated. It is a rural state and a popular tourist destination whose principal industries include agriculture and food processing (Ben and Jerry's ice cream, for example) and a flourishing tourist trade based on skiing and rural sight-seeing, located just hours away from the great urban centers of New York and Boston.

FIGURE 1. The State of Vermont

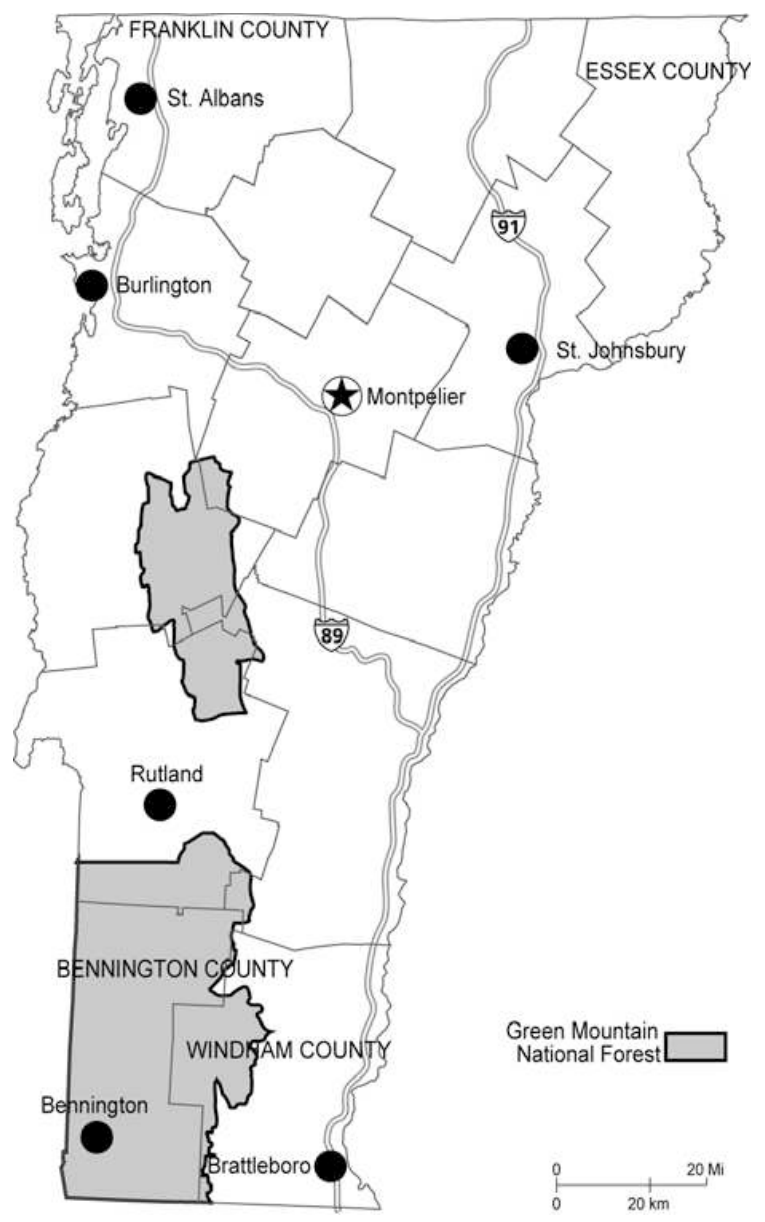

A small state with little history and low population, it is also known as a "liberal" state, in the American sense of the term. Several back-to-nature communities (communes) chose to settle in Vermont in the 1960s. In 1980, Vermont elected to the United States Congress its only Socialist representative, the Jewish (and ex-New Yorker) mayor of Vermont's economic capital, Burlington. And, following a decision in 2000 by the Vermont Supreme Court, it was also the only American state to establish civil unions, meant exclusively for same-sex couples. ${ }^{2}$

Sufficient statistical data exist to allow us to plot the distribution of same-sex couples. ${ }^{3}$ The United State Census allows same-sex couples to declare themselves as such. In addition, the State of Vermont has published statistics on the 3,600 civil unions celebrated since 2000. Together, these data allow a unique insight into lesbian and gay life in a rural milieu. 


\section{Gays and Lesbians in Rural Communities}

In general, the city is considered to be the only context that allows for the emergence of gay and lesbian culture, either because the anonymous urban space allows for the formation of individual identities ${ }^{4}$ or because gay and lesbian culture seems inseparable from the very essence of urban culture (Grésillon, 2000). Vermont is quite far from that model: it is a rural state (only seven cities hold more than 10,000 inhabitants) where lesbians and gays are present and organized.

Since the early 1990 s, several researchers have combined rural studies with gay and lesbian studies. Such interdisciplinary studies attempt to understand the importance of the "countryside" in the cultural imagination of gay and lesbian communities (Bell, Valentine, 1995), or to interpret the organization of communities (Kirey, Forsyth, 2000) outside of urban centers. This focus on rural gays finds fertile ground in the State Census that, in 1990 and again in 2000, allowed cohabitants of the same sex to declare themselves as such. If the data originating in this census have been criticized because they underestimated the number of gay and lesbian couples (Human Rights Campaign, 2002), they are still national data, consistent and readily accessible.

FIOGURE 2. Same-Sex Couples in Vermont 2000

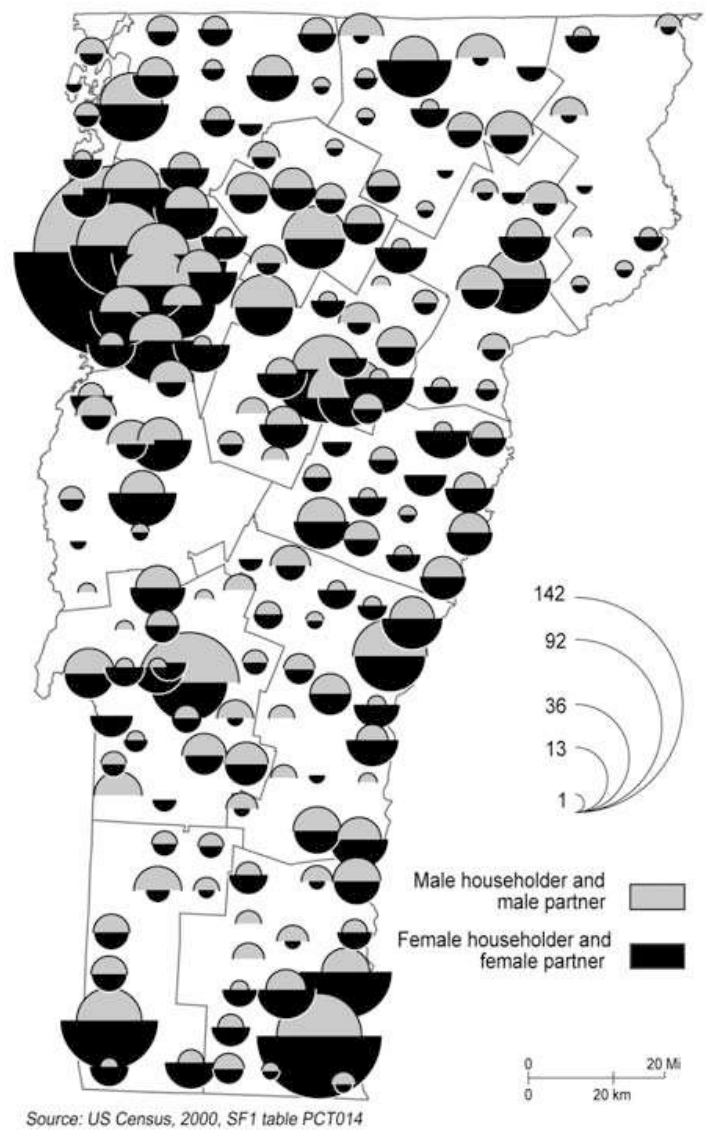

Thus, in Vermont (fig. 1 and 2), according to the U.S. Census, 1,933 households distributed over the whole state are composed of a "head of household" (a person who owns or rents the dwelling) and an unmarried partner of the same sex. A large number of towns and villages (sometimes with miniscule populations) contain at least one same-sex household: Essex County, with a population of only 6,400 people, includes nearly nine same-sex households out of every thousand. Franklin County, with 45,000 people, has seven same-sex households out of every thousand. One of the largest proportions is found in 
Chittenden (145,000 inhabitants, a quarter of the population of Vermont), which includes Burlington, the economic and educational capital of Vermont, where the first gay and lesbian organizations saw the light of day in the early 1980 s.

The greatest proportion of female couples ( $60.5 \%$ of all same sex couples) that distinguishes Vermont from the rest of the United States (where the proportion is only 49\%) is a regional peculiarity: Northampton, a Massachusetts city situated several dozen kilometers to the south, was nicknamed "Lesbianville" in the early 1990s (Forsyth, 1997). The militant mobilization of this population, mostly lesbian, bore fruit in the early 1990s (Bernstein, 2002): the right of same-sex couples to adopt a child was recognized around 1993. These same women were also in the forefront of the struggle for the right to civil unions, replacing the stereotype of the sexually promiscuous gay man (whether New Yorker or San Franciscan) with the image of a mother or of a couple enduring for decades.

\section{The Practical Effects of Civil Unions: a Bit of Tourism}

Civil unions have become an integral part of Vermont's bureaucratic culture. Three years after their establishment (July 2000), the geography that they trace is only partly reflected by the spatial distribution of gay and lesbian couples living in the state: it reflects, rather, the geography of tourism in the state of Vermont.

FIGURE 3. State of Residence for Civil Union Couples

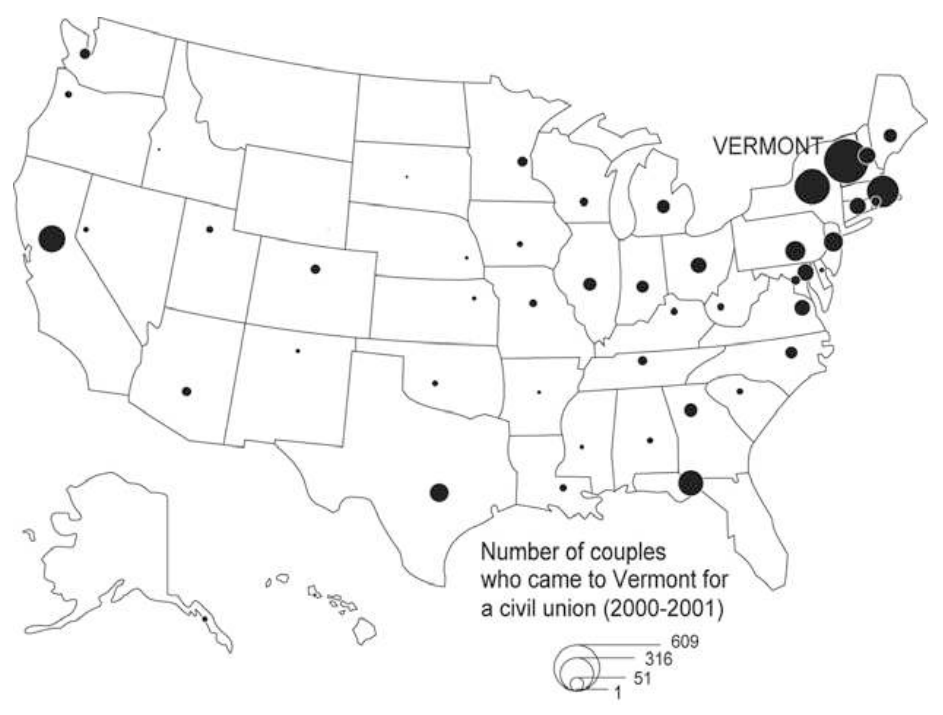


Traditionally, Vermont's economy has been based on tourism and agriculture, two industries intertwined since the end of the $19^{\text {th }}$ century (Brown 1995). More recently, since the 1980s, the state has developed a veritable industry out of "authentic" marriage as an alternative to the Las Vegas model. Travel agents offer their clients bed and breakfast/marriage packages. The success of such marketing is real. In 1980 , only $12 \%$ of heterosexuals married in Vermont came from another American state. In $2000,36 \%$ of these spouses came from elsewhere. This was made possible by the removal of hurdles in the way of marriage: the abolition of blood tests in 1986 and of the three-day waiting period in the early 90 s. In 2000, one of the last hurdles to fall was that of gender difference.

Statistics show that civil unions have insinuated themselves into the marriage-based tourist industry (fig. 3): between July 2000 and January 2002, 82\% of the 3,600 civil unions were contracted by "out-of-staters" (of which two-thirds were female), therefore by people who cannot benefit from the legal advantages brought by civil union, applicable only in Vermont. This tourism is based on proximity: only four couples from Utah (and none from North Dakota) came to Vermont to obtain their civil union, while more than 400 couples came from New York and more than 300 from neighboring Massachusetts. Given the lack of judicial sanction of civil unions outside of Vermont, however, it is interesting to note that certain residents of faraway states came to obtain a recognition of their union: a hundred Texan couples, more than 200 from California and another 200 from Florida. Civil union is not merely a contract between two people-it is a authentic ceremony recognized by a state.

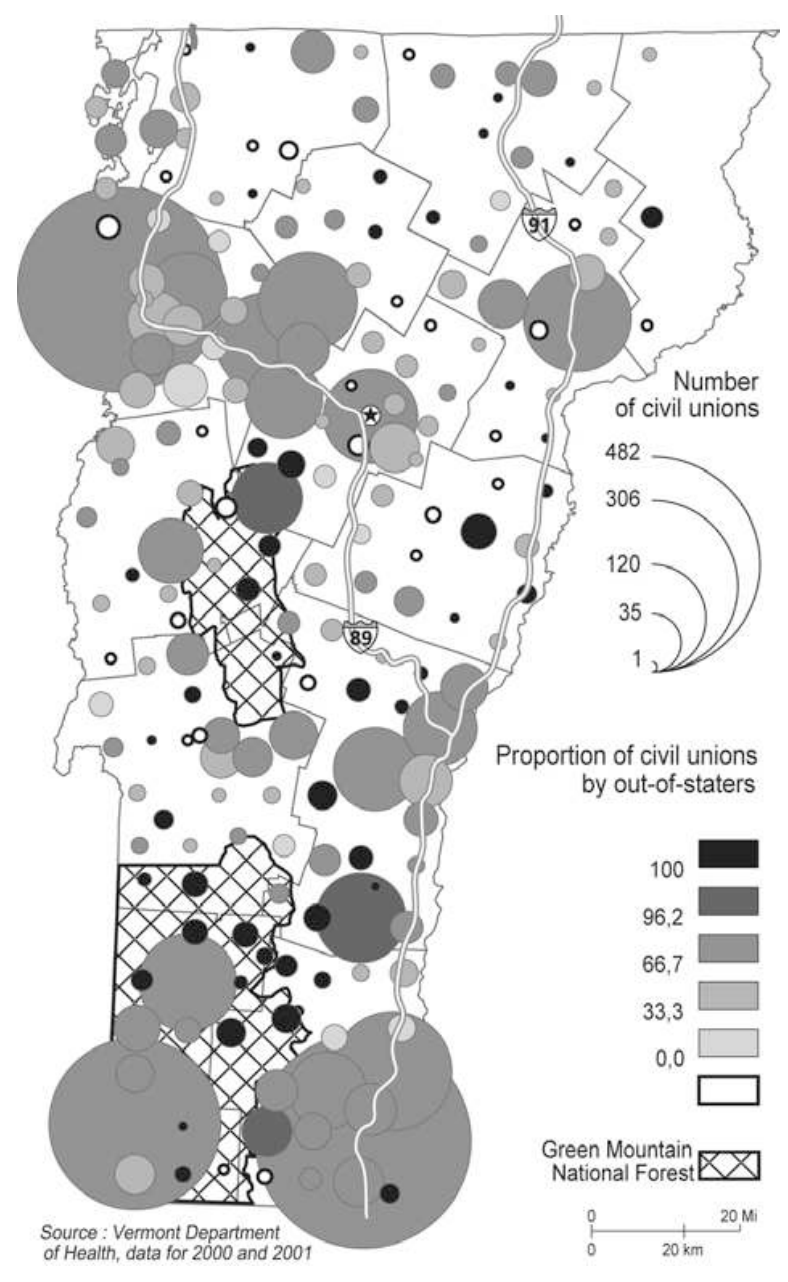


Those tourists (fig. 4) who contract a civil union do it in various places throughout Vermont. They go where there are already a large number of same-sex couples: Burlington can be reached by air or by Interstate 89; Brattleboro or Bennington are points of entry from New York, relatively close to the Hartford, Connecticut, airport. But tourists also come to marry at tourist destinations where relatively few same-sex couples live, for example, Bennington County, composed almost entirely of a nature preserve and rather politically conservative. Central Vermont, a mountainous region, difficult to reach, also attracts its share of nuptial tourists. In these two cases, rather than seeking an established gay and lesbian community, people seek rustic, natural places as a romantic backdrop to their union. Places where tourists do not venture (in blue on the map) confirm this hypothesis. Same-sex couples reside in the suburban towns and villages around Burlington and Montpelier (the capital), but these are certainly not tourist destinations.

\section{Civil Unions and the Church: Local Sociability and "Spatial Engagement"}

Civil unions have had a symbolic and practical impact on numerous churches in Vermont. In 2000 and $2001,14 \%$ of civil unions, or slightly more than 500 , were celebrated by a member of the clergy, a pastor or a rabbi. In all, close to 160 different ministers celebrated this type of union (92 pastors only celebrated one union over the two year period). If the practice of "commitment ceremonies" (the religious celebration of the engagement of same-sex couples) is common among certain denominations (Unitarian Universalists have officially allowed their pastors to perform unions for same-sex couples since the 80s), other denominations have experienced deep internecine struggles (Coulmont, 2003). Commitment ceremonies have always been understood as purely religious acts, without bearing on (or opposition to) the legal sphere. Civil unions have changed that situation. In Vermont, as in the rest of the United States, a member of the clergy who celebrates a marriage acts as an agent of the state, just as with a civil union. ${ }^{6}$ 
FIGURE 5. The First Unitarian Universalist Church of Burlington

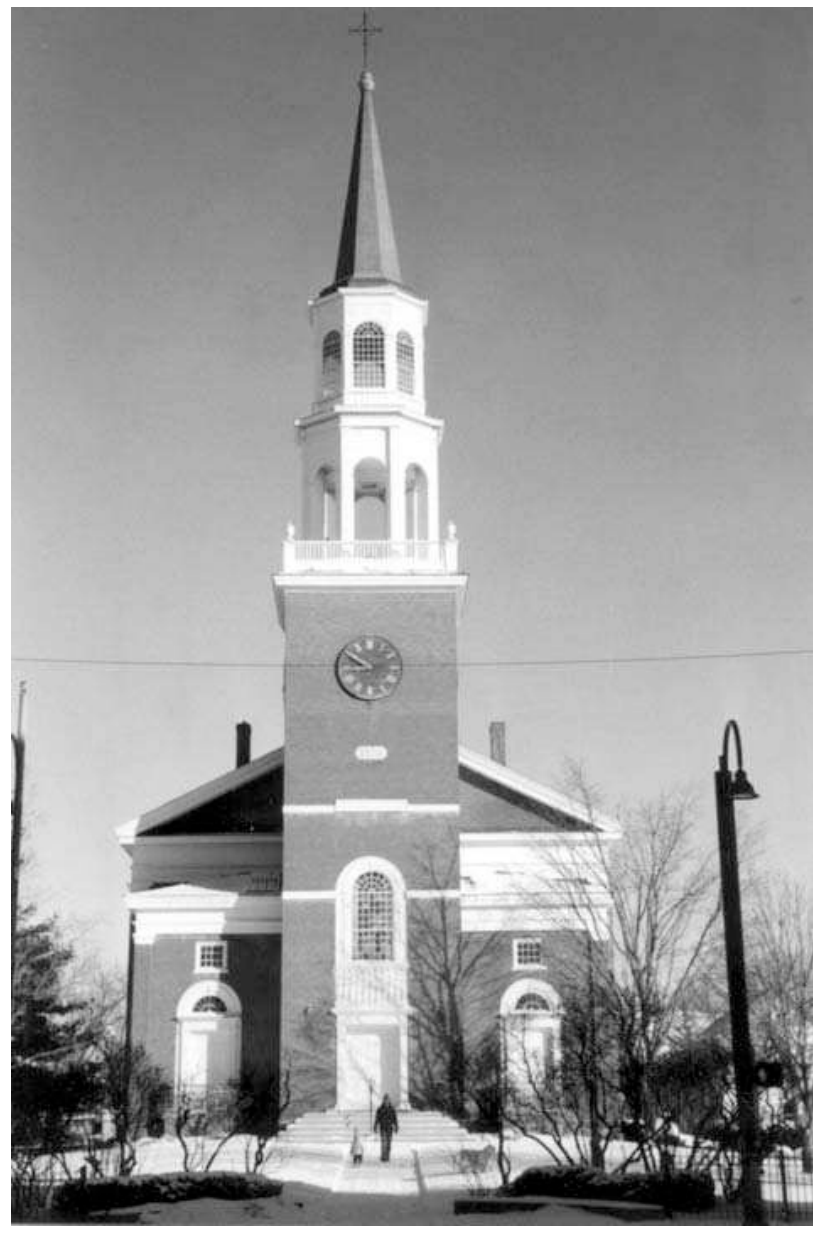

\section{The Work of the Clergy Translated into Spatial Terms, According to Two Methods}

Residence would seem to be an initial criterion for access to the services of ministers, since churches are local community centers. While only $11 \%$ of couples from other states were united at a church, $29 \%$ of the couples residing in Vermont chose a pastor to celebrate their civil union. A series of interviews shows that it was only after the law was passed that many pastors were confronted with requests for religious celebrations of civil unions, even though these couples were longstanding members of their congregations. In most Protestant churches, it would be difficult for a pastor to decide alone to celebrate civil unions, without obtaining the consent of the lay council that directs the church. Civil unions have thus encouraged the establishment of internal rules, by more or less general consensus, allowing pastors to celebrate unions of same-sex couples in the name of the church. Celebrating the unions of local gays and lesbians is thus justified as an occasion for proselytizing. The pastors hope that couples will continue to attend services and will raise their children in the bosom of the church. In fact, these pastors, members of less progressive churches than the Unitarians (Episcopalians, Congregationalists, Presbyterians, etc.) insist on developing relationships with couples that are concerned less with providing services (brief, goal-oriented encounters) than with developing personal relationships (long-term involvement, based on reciprocity). To accomplish this end, they first oblige all couples, straight or gay, to fill out a psychological profile and attend four to six sessions of conjugal counseling. 
For those churches centered in a local community there is another way of "making religion," characterized by the celebration of a great number of civil unions for non-residents. This method seems typical of Unitarian-Universalist pastors, who have been "in the business" of uniting same-sex couples for the last 20 years. The creation of civil unions has greatly developed that business. Some Unitarian churches have been quite productive: the pastors of the First Unitarian Universalist Church of Burlington (fig. 5) have celebrated more than 70 civil unions, and the pastor of St. Johnsbury has celebrated 60. Being quite dedicated, these pastors have agreed to travel sometimes far from home to celebrate unions (fig. 6) of couples whom they will probably never see again.

FIGURE 6. Travels of Some Unitarian-Universalist Ministers

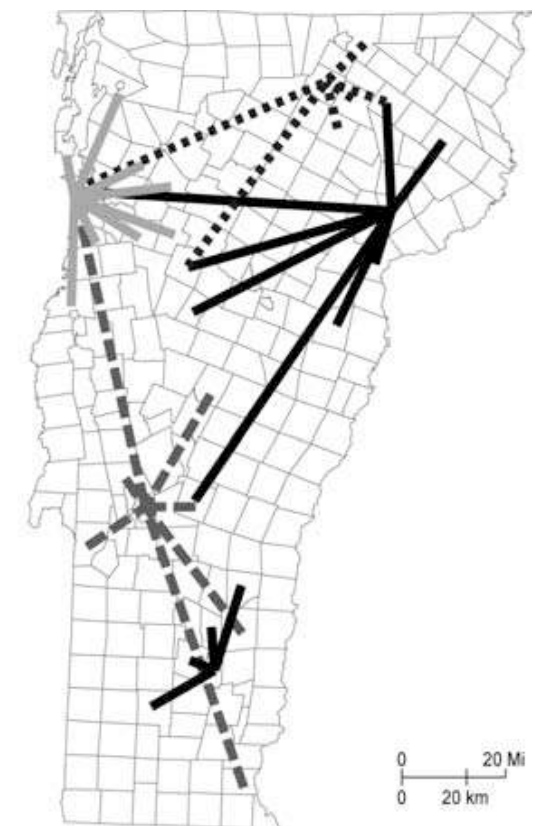

Source: Vermont Department of Health, Vital Records (data for 2000 and 2001)

Far from turning Vermont upside down, civil unions have rapidly become a part of its mountainous, pastoral and sparsely populated New England countryside. The few unions performed have been integrated seamlessly into the tourist service industry and even into the practice of some of the more progressive churches.

\section{NOTES}

1. Dictionary of American History, vol. VII, New York : Charles Scribner, 1976, 171. 
2. The circumstances leading to the adoption of this law have been well described by Eskridge, William, Equality Practice : Civil Unions and the Failure of Gay Rights (New York : Routledge, 2002).

3. These graphs were made with the aid of PhilCarto software, available on-line from http://perso.club-internet.fr/philgeo. The data come from the 2000 United States Census (www.census.gov), and from the Vermont Department of Health. My deepest thanks go to Romain Garcier for his help in elaborating this article.

4. " The complexity of the city's social and spatial organization made it possible for gay men to construct the multiple public identities necessary for them to participate in the gay world without losing the privileges of the straight." Chauncey 133-134.

5. The Unitarian Universalist Church is a small, liberal denomination without a creed. Historically, it originated from the schisms in New England during the $18^{\text {th }}$ century.

6. Vermont State Code : Sec. 5.18 V.S.A. chapter 106, § 5164, "Persons authorized to certify civil unions."

\section{WORKS CITED}

Bell, D. and Valentine, G. "Queer Country : rural lesbian and gay lives.” Journal of Rural Studies 11 (1995). 113-122.

Bernstein, M. "The Contradictions of Gay Ethnicity: Forging Identity in Vermont" Nancy Whittier, et al., ed. Social Movements: Identity, Culture, and the State. Cambridge, MA: Harvard UP: 2002.

Brown, D. Inventing New England: Regional Tourism in the Nineteenth Century. Washington: Smithsonian P, 1995.

Chauncey, G. Gay New York. New York: Basic Books, 1994.

Coulmont, B. «Églises chrétiennes et homosexualiés aux États-Unis, éléments de compréhension ». Revue française d'études américaines 95 (2003). 73-86.

Forsyth, A. "“'Out' in the Valley." International Journal of Urban and Regional Research 21 (1997). 3660 .

Grésillon, B. «"Faces cachées de l'urbain" ou éléments d'une nouvelle centralité ? Les lieux de la culture homosexuelle à Berlin». L'Espace géographique 4 (2000). 301-313.

Human Rights Campaign. "Gay and Lesbian Families in the United States: Same-Sex Unmarried Partner Households." Washington: Human Rights Campaign, $2002<$ http://www.hrc.org $>$.

Kirkey, K. and Forsyth, A. "Men in the Valley: Gay Male Life on the Suburban-Rural Fringe." Journal of Rural Studies 17 (2001). 421-441. 